\title{
ANALYSIS OF CORRECT FIREWOOD SEASONING BY SELECTED HOMEOWNERS IN THE PODKARPACIE (SUBCARPATHIAN) REGION
}

\section{Damian Kwiatkowski ${ }^{1 *}$, Krzysztof Słowiński ${ }^{1}$, Anna Kożuch ${ }^{2}$}

${ }^{1}$ Department of Forest Utilisation, Forest Engineering and Technology,

Faculty of Forestry, University of Agriculture in Krakow,

al. 29 Listopada 46, 31-425 Krakow

${ }^{2}$ Department of Ecology and Silviculture, Faculty of Forestry,

University of Agriculture in Krakow, al. 29 Listopada 46, 31-425 Krakow

\section{ABSTRACT}

Since 2008, increasing the share of renewable energy in total energy production has been a priority for all Member States of the European Union, including Poland. The combustion of biomass, and especially logs, still constitutes an important source of heat for households. However, for the process to be efficient and environmentally friendly, the firewood should be correctly prepared by bringing its moisture content down to $20 \%$ or less. The most widespread and cheapest method of reaching that target is wood seasoning. The aim of this work was to assess the correctness of firewood seasoning in the Podkarpacie (Subcarpathian) Region based on results from a study involving 150 woodburning households. Furthermore, the obtained data were used to estimate theoretical seasoning duration needed to reduce firewood moisture content down to $20 \%$.

\section{KEYWORDS}

renewable energy sources $\bullet$ biomass $\bullet$ combustion $\bullet$ firewood $\bullet$ firewood moisture content

\footnotetext{
* $\bowtie$ damian.r.kwiatkowski@o2.pl
} 


\section{Introduction}

On December 15-18, 2008 after many months of negotiations, the European Parliament adopted the so-called energy and climate package (also known as the climate package or " $3 \times 20$ " package) proposed by the EU Council at the Brussels Summit on March $8-9,2007$. It assumed a decisive action against climate change, based ultimately on four assumptions necessary for implementation by the EU Member States:

- Reducing greenhouse gas emissions by 20\% compared to 1990 levels,

- Increasing the share of energy obtained from renewable energy sources to $20 \%$,

- Increasing energy efficiency by $20 \%$ compared to forecasts for 2020 ,

- Increasing the share of biofuels in the total consumption of transport fuels by at least $10 \%$.

The implementation of the second postulate assumes primarily a reduction in the share of energy produced from high-emission hard coal, for the sake of renewable energy sources, including solid biomass (Bednarska 2008).

Estimates show that Poland has higher technical potential for renewable energy production than some Scandinavian countries, including Sweden or Denmark. Our renewable resources could potentially cover almost $50 \%$ of the total energy demand. Meanwhile, in 2010, energy from renewable sources accounted for only $9 \%$ of the total energy generated in Poland (Baum et al. 2012). Due to the fact that the hydrogeological conditions of the country limit the possibilities of developing environmentally friendly wind, hydropower or geothermal energy, Poland places the greatest hopes for obtaining energy from renewable sources in the use of biomass (Wisz and Matwiejew 2005).

\subsection{Biomass as the source of heating energy in Poland}

Biomass can take either solid, liquid or gas form, but the latter two account for only a few per cent of market share. According to data from the Polish Central Statistical Office (GUS), nearly 45\% of all energy generated from renewable sources in Poland in 2016 was produced from solid biomass (GUS - Energia 2018).

The Central Statistical Office data also shows that in 2017 solid biomass, used for heating purposes in Polish households, met $13.4 \%$ of the national demand for thermal energy. Nevertheless, the vast majority of thermal energy in Polish homes is still produced from hard coal (32\%). The second most common source of heat in households is the district heating (20.6\%).

The vast majority of thermal energy supplied to households is consumed for the purposes of house heating and hot water (GUS - Energia 2017).

According to GUS estimates in 2017, there were about 14.2 million households in Poland. Based on the above data, it can therefore be assumed that in 2017, almost 1.9 million households in the country used solid biomass for heat production (CSO Forecast... 2016). 
Of course, solid biomass is not just raw wood. According to the classification proposed by Zbytka and Adamczyk (2017), solid biomass includes, among others: sawdust, wood chips, tree trunks and branches (including those from fast-growing trees), waste and demolition wood, parts of stem plants, peat, sewage sludge or cereal grains. All of the above-mentioned raw materials constitute heating fuel, both in natural and processed state - in the form of pellets, briquettes, wood chips, logs, or pieces.

Ratajczak et al. (2011) also include tree bark, discards, and waste from the production of pulp, waste paper and wood ash lye among types of biomass.

However, firewood has the longest tradition - going back several hundred years - in terms of use in the process of combustion and energy production of all solid biomass types (Janowicz 2003). Moskalik et al. (2012) note that man has used wood for heating purposes since the dawn of time.

\subsection{Firewood as raw material for heat energy}

In 2016, as part of broadly understood forest management, a total of almost 41 million $\mathrm{m}^{3}$ of wood was obtained in Poland, including approximately 4.9 million $\mathrm{m}^{3}$ of firewood (12\%). Of this 1666 thousand $\mathrm{m}^{3}$ was the coniferous firewood (softwood), 1866 thousand $\mathrm{m}^{3}$ was deciduous firewood (hardwood), and 1389 thousand $\mathrm{m}^{3}$ was smallsize firewood (GUS - Forestry 2017).

Such a high demand for raw material for heat energy results from the fact that wood is still relatively the cheapest heat energy carrier. Considering the differences in the calorific value of fuels and the unit prices of their purchase, the supply of heat to households using hard coal, compared to burning wood, is currently $50 \%$ more expensive; heating oil is $75 \%$ more expensive; and heating using electricity is as much as $450 \%$ more expensive (Moskalik et al. 2012).

The result of the wood burning process is the production of heat energy in an average amount of about $4-4.5 \mathrm{kWh} / \mathrm{kg}$. This value is subject to noticeable fluctuations resulting from the quality of wood raw material used in the combustion process. The specific calorific value of individual wood species varies due to differences in the density of the raw material. It is estimated that the calorific value specific for all hardwood is $2100 \mathrm{kWh} / \mathrm{mp}$, while for softwood it is only $1600 \mathrm{kWh} / \mathrm{mp}$ (Ebert 2003).

However, to be able to effectively use wood as a fuel, it must possess appropriate parameters. The most important factor determining the efficient use of wood raw material as a solid fuel is its moisture content. At the moisture content of more than $50 \%$ (fresh wood), its specific calorific value is half that of completely dry wood fuel, due to energy losses for heating and water evaporation (Gradziuk 2002).

Like many other sources, Mirowski (2008) suggests that the optimal moisture content for firewood is $20 \%$, which requires the raw material to undergo atmospheric drying for a period of about 18 months. Burning wood with a higher moisture content - that is, above $20 \%$ - is not economically justified, as evaporation of water from the raw material causes a clear energy loss, which directly affects the cost of heat generation. In addition, chemical compounds, dust and soot released during the combustion 
process may damage the chimney installation or boiler furnace. These substances also place a great burden upon the natural environment (Chrapka 2011).

The latter argument is a real problem in large urban agglomerations, which have been conducting costly activities for years to combat smog and broadly understood environmental pollution. One of the ways to implement the above assumptions is to introduce legal regulations, including the so-called "anti-smog resolutions" that should limit bad practices, including those pertaining to the use of solid fuels.

Podkarpacie (Subcarpathian) Region, which was the research area under this study, also adopted such resolution.

\section{Objective and scope of the work}

The purpose of the present study is to analyse the moisture content of solid biomass in the form of firewood collected in households in the Podkarpacie Region, in terms of compliance with the requirements of Resolution No. LII/869/18 of the Podkarpacie Regional Assembly of April 23, 2018 regarding the introduction of restrictions on the operation of installations in which fuel is burned in the region (Journal of Laws of the Podkarpacie Region, May 18, 2018, item 2498), prohibiting the use of solid biomass as a fuel whose operating moisture content exceeds $20 \%$.

An additional objective of the study was to determine the optimal seasoning time of the raw material until it reaches the moisture content prescribed in the resolution (20\%).

The scope of work included examining the moisture content of firewood stored in private premises, and conducting a survey among homeowners on the length of seasoning time and how they store wood, among other things.

The following working hypotheses were adopted in order to meet the objective of the conducted research:

1. The owners of households in the Podkarpacie Region who produce thermal energy from burning firewood use for this purpose raw material with the moisture content not exceeding $20 \%$.

2. Obtaining $20 \%$ moisture content of wood raw material requires atmospheric seasoning for 18 months.

3. Hardwood firewood, due to the higher density of the raw material, requires longer seasoning than softwood, in order to achieve moisture content of $20 \%$.

\section{Material and methods}

In the years 2017-2018, moisture content of firewood was tested in the raw material collected in 150 households throughout the whole Podkarpacie Region. At the research stage, the focus was on the tree species most commonly used as firewood: pine and spruce (softwood), as well as beech, hornbeam and oak (hardwood). The owners in 
individual households themselves indicated the raw material, which had been subjected to earlier seasoning, and intended for current use. The moisture content of the raw material was measured using a BASETech BT-300 resistance hygrometer. The measuring electrodes of the device were hammered into the wood raw material without bark at half the length of the material's side surface, at an angle of $45^{\circ}$ in relation to the longitudinal axis of wood fibres (Fig. 1).

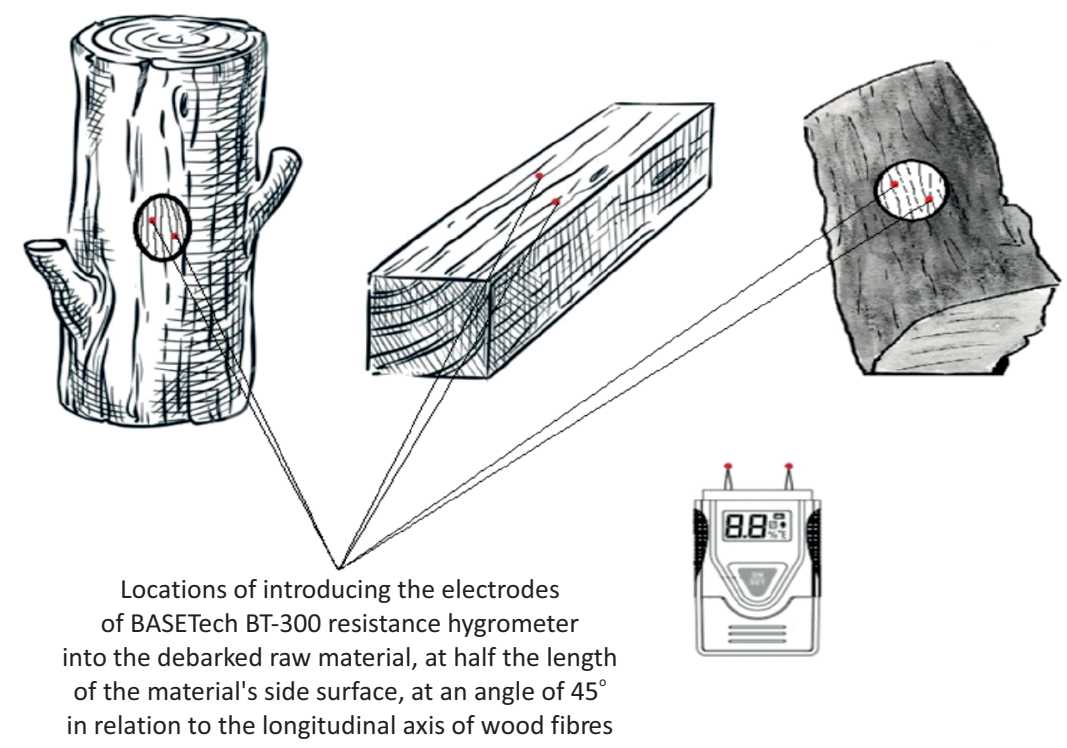

Fig. 1. Location and manner of measuring the moisture content of the raw material using the BASETech BT-300 hygrometer

It should be noted here that the BASETech BT-300 hygrometer is a simple measuring device, and it does not allow for introducing any corrections that will result from the variability of the wood species tested, which has a direct impact on its density, as well as the temperature of the tested raw material. The abovementioned simplification means that the measurement error of the device may be as high as $4.5 \%$.

Measurements were repeated several times for each type of wood in each household, and the average result was recorded in the table. Due to the fact that a significant number of farms had used softwood as well as hardwood, 250 average measurement results were accumulated. While testing for the moisture content of the raw material, a short survey was conducted among the homeowners, aimed at determining the seasoning time of the wood.

Please note: for the purpose of this study, it has been assumed that all information obtained from the homeowners in the survey is true, accurate and reliable.

The collected test results were then subjected to a statistical significance analysis of differences between the values for softwood and hardwood. In the first stage of the analy- 
sis, the compatibility of the variable's distribution with the normal distribution (Gaussian curve) was examined, followed by proper analysis using the ANOVA parametric test.

\section{Study results and discussion}

The basic statistical parameters for the data collected during the implementation of the study are shown in Table 1.

Analysis of the collected data shows that the average moisture content of wood raw material for all 250 measurements is $17 \%$, with a standard deviation of 3.54 . The minimum moisture content found during tests was $11 \%$, while the maximum was $30 \%$. It should be noted that as much as $86 \%$ of all measurements ( 215 of 250 ) showed the moisture content of lumber at a level not higher than $20 \%$, and therefore, this raw material meets the requirements imposed by the current "anti-smog resolution" for the Podkarpacie Region and is suitable for use as solid fuel. For the remaining 35 results (14\%), the moisture content of the wood was determined as higher than $20 \%$, and thus, in its present form, the raw material cannot be used as solid fuel.

The obtained results confirm the first of the scientific hypotheses: owners of households in Podkarpacie Region season firewood until it reaches moisture content below $20 \%$, and they mostly use only such raw material for the production of heat energy.

In order to verify the second research hypothesis, the following procedure was adopted: based on all the data collected during the tests, charts were prepared (separately for softwood and hardwood) using the STATISTICA software, showing the correlation between the average moisture content of the wood and the seasoning of the raw material.

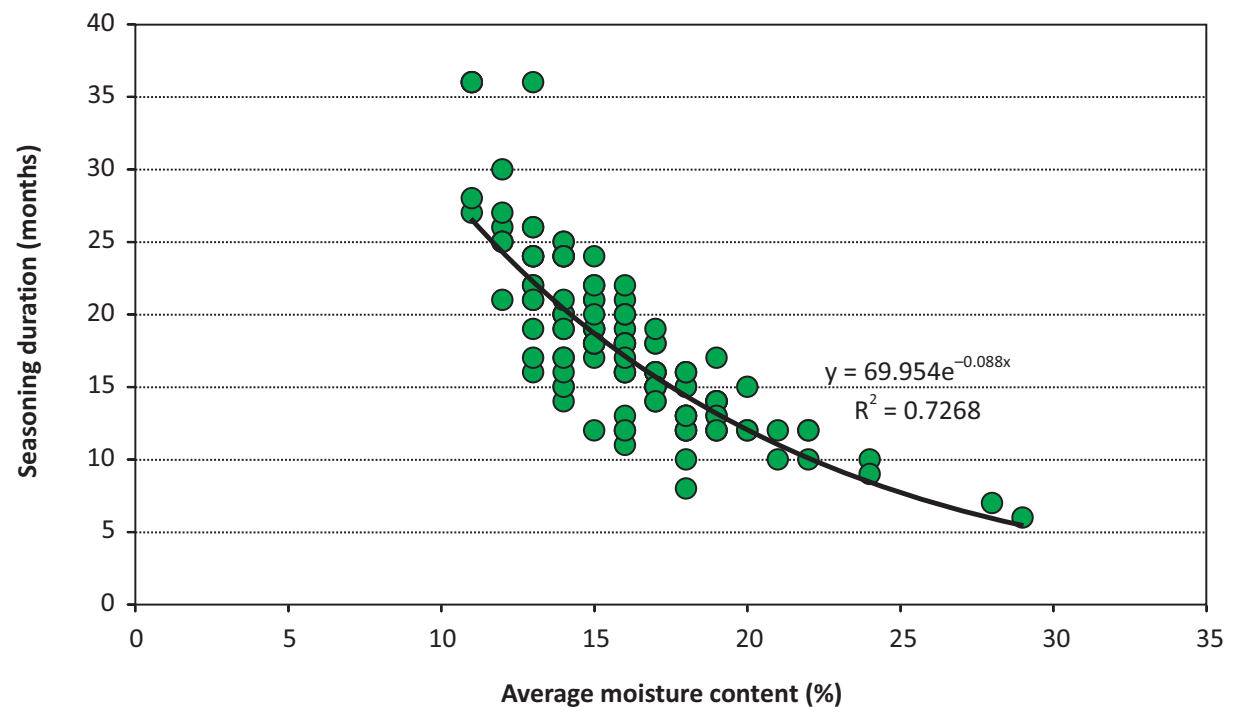

Fig. 2. Moisture content of softwood depending on the duration of its seasoning 


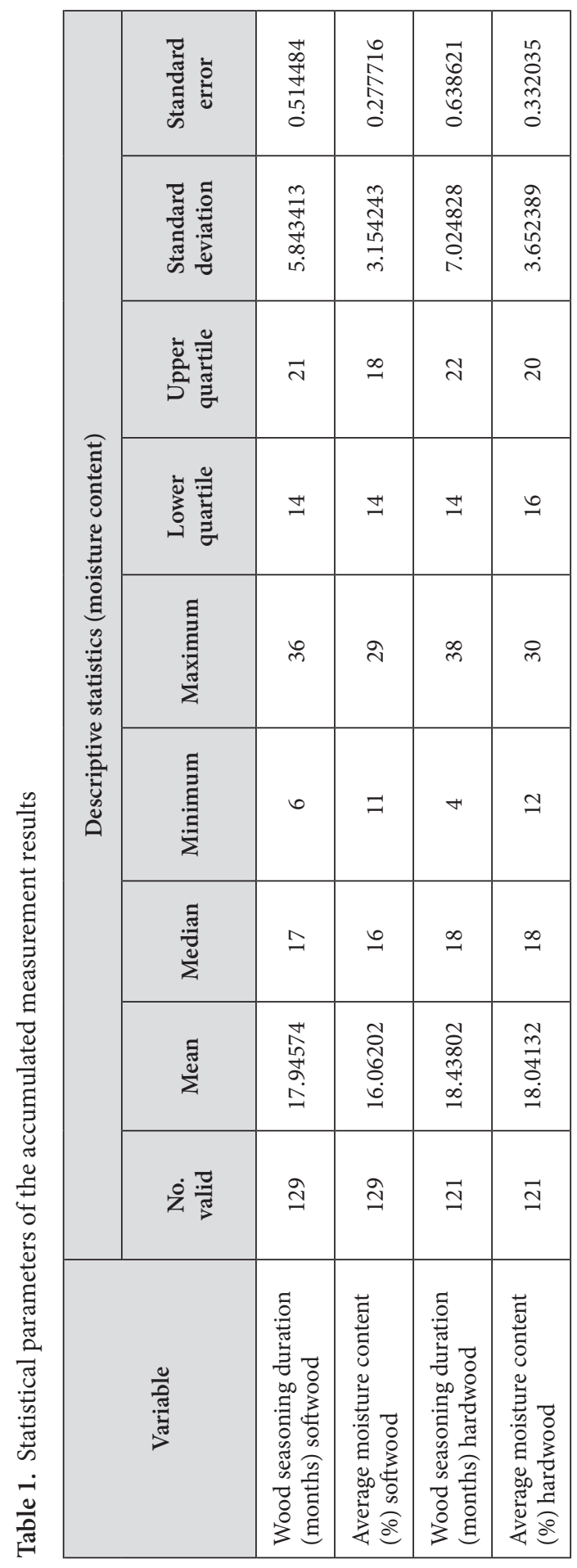




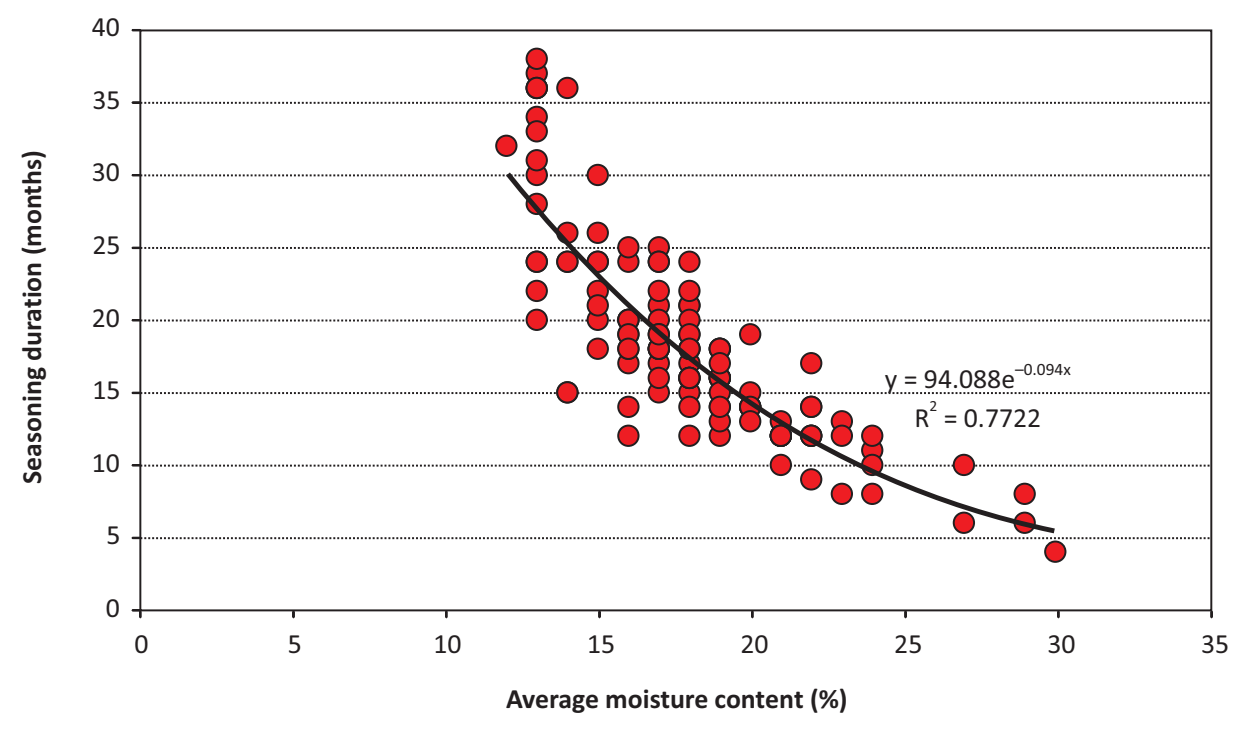

Fig. 3. Moisture content of hardwood depending on the duration of its seasoning

Then, on the basis of the trend lines drawn and the equations that describe them, the theoretical seasoning period was calculated for both types of wood, of the duration that would allow the raw material to reach the moisture content of $20 \%$ :

- Softwood:

$$
y=69.954 \cdot e(-0.088 \cdot 20) \sim 12 \text { months }
$$

- Hardwood:

$$
y=94.088 \cdot e(-0.094 \cdot 20) \sim 14,4 \text { months }
$$

In order to determine the statistical significance of differences between the average moisture content of softwood and hardwood, the collected data was subjected to statistical analysis. In the first stage of the analysis, the compliance of variable distributions with the normal distribution (Gaussian curve) was examined. In the case of coniferous wood (softwood), a variable distribution similar to the normal distribution was obtained, while in the case of deciduous wood (hardwood) - the variable distribution deviated from the normal distribution. In view of the above, it was decided that the arcsine (Bliss's) transformation should be applied, typically used for data having a binomial distribution expressed as percentage.

After applying the aforementioned data transformation, a normal distribution of the tested moisture content was obtained for both softwood and hardwood (Table 2).

Analysis using a one-dimensional significance test (ANOVA parametric test) demonstrated the statistical significance of differences between the average moisture of hardwood and softwood (Table 3). 
Table 2. Results of the distribution analysis for the average moisture content of wood

\begin{tabular}{|l|c|c|c|c|c|c|}
\hline \multirow{2}{*}{ Variable } & \multicolumn{7}{|c|}{ Normality test (moisture content) } \\
\cline { 2 - 7 } & $\mathrm{N}$ & $\max . \mathbf{D}$ & $\begin{array}{c}\text { K-S } \\
\mathbf{p}\end{array}$ & $\begin{array}{c}\text { Lillief. } \\
\mathbf{P}\end{array}$ & $\mathrm{W}$ & $\mathbf{p}$ \\
\hline $\begin{array}{l}\text { Hardwood } \\
\text { (Bliss) }\end{array}$ & 129 & 0.097749 & $\mathbf{p}<\mathbf{0 . 2 0}$ & $\mathrm{p}<0.01$ & 0.948207 & 0.000088 \\
\hline $\begin{array}{l}\text { Softwood } \\
\text { (Bliss) }\end{array}$ & 121 & 0.108589 & $\mathbf{p}<\mathbf{0 . 1 5}$ & $\mathrm{p}<0.01$ & 0.955741 & 0.00055 \\
\hline
\end{tabular}

Table 3. Results of the ANOVA parametric test for average moisture content of wood

\begin{tabular}{|l|c|c|c|c|c|}
\hline \multirow{3}{*}{ Result } & \multicolumn{5}{|c|}{ One-dimensional significance tests according to Bliss (moisture content) } \\
\cline { 2 - 6 } & \multicolumn{5}{|c|}{ Sigma-restricted parametrization } \\
\cline { 2 - 6 } & SS & $\begin{array}{c}\text { Degrees } \\
\text { of freedom }\end{array}$ & MS & F & p \\
\cline { 2 - 6 } & 44.86808 & 1 & 44.86808 & 22903.52 & 0 \\
\hline Absolute term & 0.04264 & 1 & 0.04264 & 21.76 & 0.000005 \\
\hline Type of wood & 0.48583 & 248 & 0.00196 & & \\
\hline Error & & \multicolumn{5}{|c|}{} \\
\hline
\end{tabular}

\section{Conclusions}

The results obtained in the course of the conducted research show that the owners of private households in the Podkarpacie Region in the vast majority show a high awareness of how to correctly prepare firewood. In $86 \%$ of households, wood is seasoned for a sufficiently long time, and the moisture content of the raw material at the time of combustion complies with the adopted standards. The introduction of the "anti-smog resolution" in the Podkarpacie Region in 2018 did not cause a breakthrough in the manner of managing firewood in households. Before the entry into force of the abovementioned legal regulation, the method of seasoning firewood, in the vast majority of cases, was already correct and efficient.

Only a dozen or so per cent of households in Podkarpacie Region are forced to extend the seasoning of the raw material by several (or a dozen or so) months in order to reduce the moisture content of burned firewood to a level below $20 \%$.

With respect to the theoretical seasoning period of wood raw material, the research showed that, as proposed by Mirowski (2008), the 18-month time duration seems unnecessary for the raw material to reach optimum moisture content. The data collected 
as part of the research presented herein shows that the period necessary for softwood to reach $20 \%$ moisture content requires its seasoning for about 12 months, while for hardwood it is just over two months longer. Both the above-mentioned analysis and the result of the parametric ANOVA statistical test, confirming the significance of differences between the results of moisture content measurements for both types of raw material, clearly confirm the last of the research theses, stating that hardwood requires a longer seasoning period than softwood, due to greater density of the raw material.

This does not mean, however, that it is mandatory to shorten the seasoning of firewood throughout whole country. The storage duration of the raw material is closely related with storage conditions; and its value is undoubtedly influenced by local climate conditions, including average ambient temperature, solar exposure, wind exposure, total precipitation, close proximity of reservoirs and watercourses, shading, as well as the human factor - the way the wood is stacked, the type of structure of the building used for storing raw material, and many other aspects.

It is also worth noting that the research carried out within the framework of this study required the assumption that all data obtained from the homeowners in the survey is truthful, accurate and reliable.

In order to verify the correctness of the results obtained, it would be necessary to eliminate the human factor, and carry out similar tests under controlled conditions, this time using devices with higher measurement accuracy than the presently used BASETech BT-300 moisture meter, which is burdened by a relatively large measurement error.

\section{References}

Baum R., Wajszczuk K., Wawrzynowicz J. 2012. Modelowe rozwiąanie logistyczne dla lokalnego rynku biomasy. Logistyka, 4: 846-854.

Bednarska A. 2008. Europejskie plany poprawy efektywności energetycznej. Biuletyn URE, 1: 8-10. Chrapka R. 2011. Wilgotność drewna opałowego. https://www.info-ogrzewanie.pl/artykul,id_m-100149,t-wilgotnosc_drewna_opalowego.html (accessed: 03.12.2018).

Ebert P. 2003. Palenie drewnem we wszystkich rodzajach pieców. Studio Astropsychologii, Białystok.

Główny Urząd Statystyczny. 2016. Prognoza gospodarstw domowych na lata 2016-2050.

Główny Urząd Statystyczny. 2017. Raport Energia 2017.

Główny Urząd Statystyczny. 2017. Raport Leśnictwo 2017.

Gradziuk P. (red.). 2002. Biopaliwa. Wydawnictwo Wieś Jutra, Warszawa.

Janowicz L. 2003. Cechy fizyczne i cieplne biopaliw statych. Badania właściwości i standaryzacji biopaliw stałych. Materiały Seminaryjne Europejskiego Centrum Energii Odnawialnych, Warszawa.

Mirowski A. 2008. Kotty spalajace i zgazowujące drewno, wyd. I. Akademia Firmy Viessmann, Mysłowice.

Moskalik T., Nowacka W., Sadowski J., Zastocki D. 2012. Rynek drewna energetycznego w Polsce jako element rozwoju regionalnego. Studia i Materiały CEPL w Rogowie, 222-230. 
Ratajczak E., Szostak A., Bidzińska G., Herbeć M. 2011. Analiza rynku biomasy drzewnej na cele energetyczne. Etap II: Potencjalna podaż biomasy drzewnej w kierunkach jej energetycznego wykorzystania i przewidywany popyt na nośniki energii z biomasy drzewnej w Polsce do 2015 roku. Instytut Technologii Drewna, Poznań (maszynopis).

Uchwała nr LII/869/18 Sejmiku Województwa Podkarpackiego z dnia 23 kwietnia 2018 r. w sprawie wprowadzenia na obszarze województwa podkarpackiego ograniczeń w zakresie eksploatacji instalacji, w których następuje spalanie paliw, Dz. U. Woj. Podk. z dnia 18 maja 2018 r., poz. 2498.

Wisz J., Matwiejew A. 2005. Biomasa - badania w laboratorium w aspekcie przydatności do energetycznego spalania. Energetyka.

Zbytek Z., Adamczyk F. 2017. Możliwości wykorzystywania biomasy stałej. Część 1. Uwarunkowania prawne i podział biomasy stałej. Technika Rolnicza, Ogrodnicza, Leśna, 2, 26-28.

\section{ANALIZA POPRAWNOŚCI SEZONOWANIA DREWNA OPAŁOWEGO W WYBRANYCH GOSPODARSTWACH DOMOWYCH NA TERENIE WOJEWÓDZTWA PODKARPACKIEGO}

\section{STRESZCZENIE}

Zwiększenie udziału odnawialnych źródeł energii w jej produkcji stało się w 2008 roku jednym z priorytetów gospodarczych dla wszystkich krajów Wspólnoty Europejskiej, także dla Polski. Spalanie biomasy, w szczególności drewna kawałkowego, wciąż stanowi istotne źródło energii cieplnej w rodzimych gospodarstwach domowych. Aby jednak proces ten był efektywny i zarazem ekologiczny, należy zadbać o odpowiednie przygotowanie surowca drzewnego, polegające na obniżeniu jego wilgotności do poziomu poniżej 20\%. Najpowszechniejszym i najtańszym sposobem na osiągnięcie ww. celu jest odpowiednio długie sezonowanie drewna. Celem niniejszego opracowania jest określenie poprawności sezonowania surowca drzewnego opałowego na terenie województwa podkarpackiego na podstawie badań przeprowadzonych w obrębie 150 gospodarstw domowych. Ponadto, na podstawie zgromadzonych danych, dokonano oszacowania teoretycznego okresu sezonowania drewna, niezbędnego do obniżenia jego wilgotności do poziomu $20 \%$.

\section{SŁOWA KLUCZOWE}

odnawialne źródła energii • biomasa • spalanie • drewno opałowe • wilgotność drewna 